\title{
CONCEPTUAL PERSPECTIVE OF VALUE FOR THE CLIENT: A STRATEGY FOR MARKET EXPANSION
}

\author{
Luis Carlos Alves da Silva \\ Universidade de Santa Cruz do Sul, Brazil \\ E-mail: luiscarlosalves0207@gmail.com \\ Maicon da Silva \\ Universidade de Santa Cruz do Sul, Brazil \\ E-mail: maicon213@bol.com.br
}

Submission: 3/31/2020

Accept: 6/3/2020

\section{ABSTRACT}

This article aims to analyze the conceptual perspective of value for the client as a strategy of market expansion. The research is the result of a literature review, followed by an exploratory analysis of the publications carried out in the last decade on the concept of value theme based on Woodruff's proposal (1997), which presents a new philosophy for the definition of Value. Thus, the present study, from the perspective of a theoretical essay, addresses the question of value and its contextualization's, where the concept of value is emphasized according to the theoretical marketing framework. In addition, the possible uses of value in marketing activities were highlighted, such as: market analysis and segmentation, positioning, planning and development of products and brands and communication strategy.

Keywords: conceptual perspective of value; market expansion; value cocreation. 
DOI: 10.14807/ijmp.v12i2.1324

\section{INTRODUCTION}

In recent years, marketing literature is quite fragmented, there is no single and consensual theory, thanks to the division of areas and sub disciplines (Relationship Marketing, Network Marketing, Social Marketing, among others), thus emerging new perspectives emerging from sub disciplines, which rethink Marketing, being remarkable the intercontamination of concepts, although with (sometimes) different definitions, between the various theories and schools of thought that permeate marketing (Gummesson, 2007; Vargo \& Lusch, 2012).

In this context, the role of Marketing is to assist the client in its creation of value (Lindgreen \& Wynstra, 2005). Value results from a particular benefit of an entity (producer and/or supplier), and may be related to social values (axiology ${ }^{1}$ ), esteem, use, exchange and cost (Lindgreen \& Wynstra, 2005). From this, value is approached as a theme of marketing literature in different contexts, where marketing administration involves the identification and satisfaction of the human and social needs of customers.

For a better understanding, Vargo and Lusch (2007) defines that the concept of value in economics is added and exchange, and, increase in monetary value (along the value chain). It should be noted that of all the values that axiological theories take into account, economic science is of interest only to economic value (Jensen, 2005; North, 1992).

Thus, the concept of value in marketing receives influences from various areas of knowledge (Economics, General Administration, Sociology, Psychology, among others). In the context of the exchange, the value was at first the focus of the study of economics, as Richins explains (1994, p. 504): "the economic literature gave way to value within the context of the exchange; the value of a product to a consumer is represented by the price it expects to pay and stems from the usefulness or satisfactions that the product provides [...]".

Furthermore, the fundamental assumption of marketing lies in the principle that the consumer chooses between different offers in which it provides him with greater value. "Customer value, which is a central concept of marketing, can be considered as a combination of quality, service, price (QSP), called the customer's value triad" (Kotler, 2012, p. 9). In this same line the value delivered to the customer is the difference between the total value for the

\footnotetext{
${ }^{1}$ Axiology is a branch of philosophical reflection committed to establishing a hierarchy of values, being the set of values accepted and followed by a given society or social group.
} 
DOI: 10.14807/ijmp.v12i2.1324

customer and the total cost for the customer. The total value to the customer is the set of benefits that customers expect from a particular product and/or service, which influence the purchase decision of the final consumer.

In this way, consumers evaluate which offer will provide the highest added value to the customer. They always seek to maximize value, within the constraints imposed by the costs involved in the search and by the limitations of knowledge, mobility and income. In these terms, the present study aims to analyze the conceptual perspective of value for clients, as a strategy for marketing expansion, understanding the state of the art on the theme proposed in the research, through the analysis of the theory contextualized in the last decade on the theme of value co-creation.

Thus, the importance of this article and its contributions to the academic environment, aligns with the different contexts related to marketing administration, more specifically to the concept of value to the client, providing a vision in which it is focused on market expansion strategies, being possible to think about market actions in different market segments.

From the proposed analysis, we seek to raise the objections about the studies on the concept of value for customers from the perspective of marketing administration, from an analysis focused on market expansion. Thus, we sought to analyze the factors associated with marketing and its contextualization's, understanding the state of the art on the theme proposed in this research. It is therefore noteworthy that the debate is situated. It is necessary to advance in the understanding of the phenomenon of marketing focused on the concept of value for the client. For this, discussions about the theoretical essay proposed in this article are presented, seeking to investigate ways and/or possibilities for further studies.

\section{FACTORS ASSOCIATED WITH MARKETING}

\subsection{Marketing Concept}

The definition of marketing has undergone changes over the years. To this end, the prehistory of marketing is exposed, where it is identified that its activities were developed only as trade practices, it is believed that only in 1900 it was recognized as science (Fonseca, 2015).

In the period comprising 1900 to 1960, theories followed a traditional line of thought without many conceptual changes, according to the standards of the time. From 1960 marketing moves to the period of differentiation, in this context Oliveira, Damacena and Brambilla (2014) defined this macro period of marketing as a decision-making activity aimed at satisfying the client profitably for the company and making the best decisions about the marketing mix, better 
DOI: 10.14807/ijmp.v12i2.1324

known as the marketing compound or 4Ps (product, price, square and promotion). This view is based around the production and transfer of value through company assets to the customer.

Already in 1980, it is characterized as the period of the emergence of marketing and marketing gurus for medium and small companies, at that time new references are beginning to emerge not based on the 4Ps and more independent of the microeconomic pattern, centered on the company, giving rise to different lines of thought around relationship marketing and its developments, quality management, market orientation, value chain offering and management, resource management and networks (Vargo \& Lusch, 2004). It was also at this time that Service Marketing emerged as a sub discipline of the marketing area, which aimed at a kind of independence from the vision of products (Shostack, 1977).

From 2000, we moved to the period of the Post-Industrial Society, characterized by strong technological advances, facilitating access to information for all. Vargo and Lusch (2004), suggested that marketing thinking evolves into a new dominant logic (that of service), which is increasingly present, away from the exclusive vision of the exchange of tangible goods (manufactured things) and towards an exchange of goods (skills, expertise and processes), thus moving towards a more comprehensive and inclusive logic.

In this context, the concept of marketing has been discussed in the last three decades, considering factors such as market change, active presence of the consumer in the processes of value co-creation and relationship marketing. The traditional idea of exchange, present in marketing definitions, has received the approach of exchange plus interactions between companies and consumers. Likewise, the concept of value in use in creating value for consumers, has grown in importance in marketing literature, for example it is mentioned that the American Marketing Association has updated the definition of marketing and included value for the consumer and consumer relationship in the definition (Dietrich, Brasil \& Cold, 2013).

For this new vision, Oliveira, Damacena and Brambilla (2014), coined the term Dominant Logic of the Service, refined several times, in which every consumer was determined as a value co-creation, in addition to the other premises that were restructured. Thus, this service should not have its interpretation restricted to traditional concepts that treat it as residual (all that is not very tangible), something offered to improve a good (service as added value), or what has been classified as industries of service (health, government, education). 
DOI: 10.14807/ijmp.v12i2.1324

Fonseca (2015), corroborates this view, that through the different definitions of marketing over time, the type of orientation differs. For, first, the orientation for the product / sales is highlighted. Later it is perceived that the importance is attributed to customers and their relationship. With the latest definition society in general and the co-creation of value begins to play an essential role in the evolution of marketing.

\subsection{Value Concept}

The concept of value has been widely discussed as a critical variable. The latest research shows a clear tendency to understand the customer value produced not by the production company, but by the consumer when using the product and when it is interacting with suppliers in the process of co-creation with them. Previous research has cited that consumers assess the value of products based on what they receive and what is sacrificed. The notion that only the consumer can assess the value of goods and services had already been expressed by (Dietrich, Brasil, \& Cold, 2013). Peter Drucker in the book "The Theory of the Business" (1994), noted that a company's first task is to create consumers. But today, consumers analyze various factors such as variety of brands, prices and suppliers. And your task when aiming for a product is to look for the one that offers you an offer that will deliver you the greatest value.

For Saraceni (2015), the concept of value has been investigated and conceptualized in different areas of knowledge such as Economics, Sociology, Anthropology, Psychology and Social Psychology, having a very subjective definition when looked at from the point of view of Administration. The typologies of values are as old as the initial effort to know these guiding principles, where consumers are considered value maximizers, limited by costs, mobility and income.

Identifying how to provide superior customer value is a challenge in today's administration. Companies that focus on creating superior value for their customers, rather than selling the company's products, seek first to identify current and future customer problems, and then try to find solutions to it. These solutions may involve the creation of new products and services, the integration of offers from other competitors (through alliances), and even recommend to them another supplier (Saraceni, 2015).

In this way Las Casas (2008), says that the concept of value by organizations cannot happen only with the identification of what customers want and with the adaptation of marketing activities in relation to marketing. "In this new economy, companies need to make consumers participate in value creation (Las Casas, 2008, p. 21)". 
INDEPENDENT JOURNAL OF MANAGEMENT \& PRODUCTION (IJM\&P)

http://www.ijmp.jor.br

v. 12, n. 2, March-April 2021

ISSN: 2236-269X

DOI: 10.14807/ijmp.v12i2.1324

\section{CUSTOMER PERSPECTIVE VALUE vs. MARKET EXPANSION STRATEGY}

According to the marketing vision, Woodruff (1997, p. 140) comments that value can be considered from the perspective of the organization and the client. The organization's perspective analyzes what the client represents of value for an organization, considering the quantification of its value to the owners. This value approach refers to customer equity translated by "customer value". In principle, when we have customer-oriented market expansion strategies, they must be planned from the situation that fully meets the purpose, environment and training of the organization to provide value to the client. These are ideal situations of easier and faster implementation, and without the need for major and costly transformations (Costa, 2006).

According to Slack (1998), value from the customer's perspective can be defined as the degree of importance that the consumer attributes to the good or service. Thus, value is fundamental for customers, and is related to their perception of what is offered to them. Therefore, the process of determining value for the client must be done in a systematic and collaborative way. On the other hand, when the value to the client is guided as a strategy of market expansion are made through initiatives within the internal and external relationships of the organization, both reactively and proactively (Child, 1997).

More and more people are willing to pay to experience sensations and not simply purchase products and/or services (Schmitt, 2002), so customer experience management is one of the most important ways to drive higher value-added service innovations (BERRY ET AL., 2006). Figure 1 illustrates the perspective of customer value-oriented processes linked to market expansion strategies.

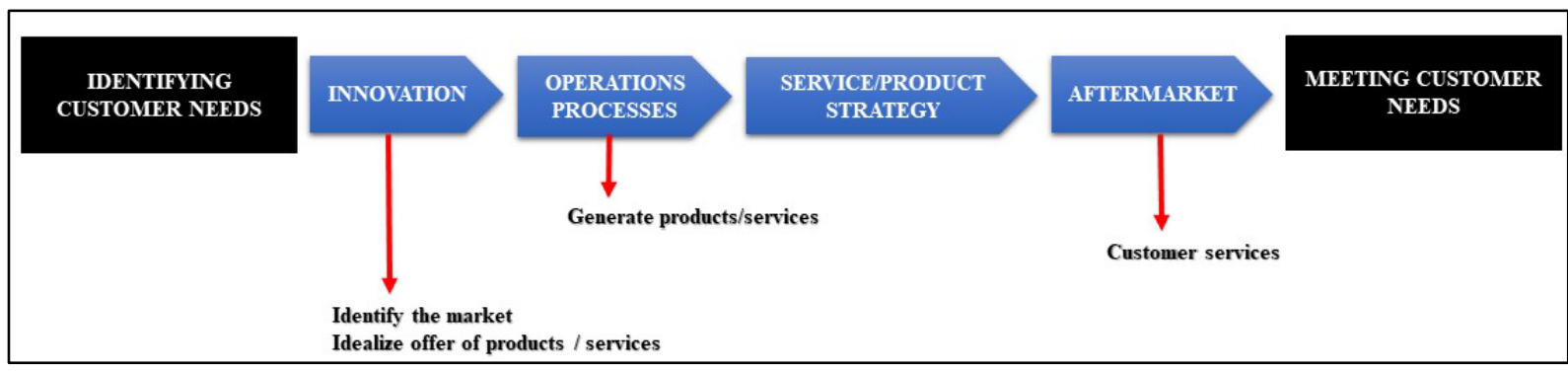

Figure 1: Customer Value x Market Strategy

Source: prepared by the authors, based on the research

Figure 1 presents the process that indicates how a company can generate value for the client, which is one of the great challenges of companies. In this sense, an organization, when facing the external world in which it operates or intends to act, to the search for market 
DOI: 10.14807/ijmp.v12i2.1324

strategies to build its future, needs to be able to individualize, for each of the specific areas, which distinctive strategies are more recommended in each case (COSTA, 2006).

For Cobra and Ribeiro (2000) customers know what their needs are, but often cannot attribute the real value to their demands. The authors state (2000, p. 118-119) that "value from the customer's perspective is constituted from information obtained through interviews with several consumers (customers) of each important segment". According to Prahalad et al. (2004) the strategy aimed at market expansion is the means of how the organization will become competitive, the goals that the company seeks through operational processes that are sales, distribution, labor, purchases, lines of products, marketing, target market and finance. Figure 2 illustrates how market strategies are generated through added value.

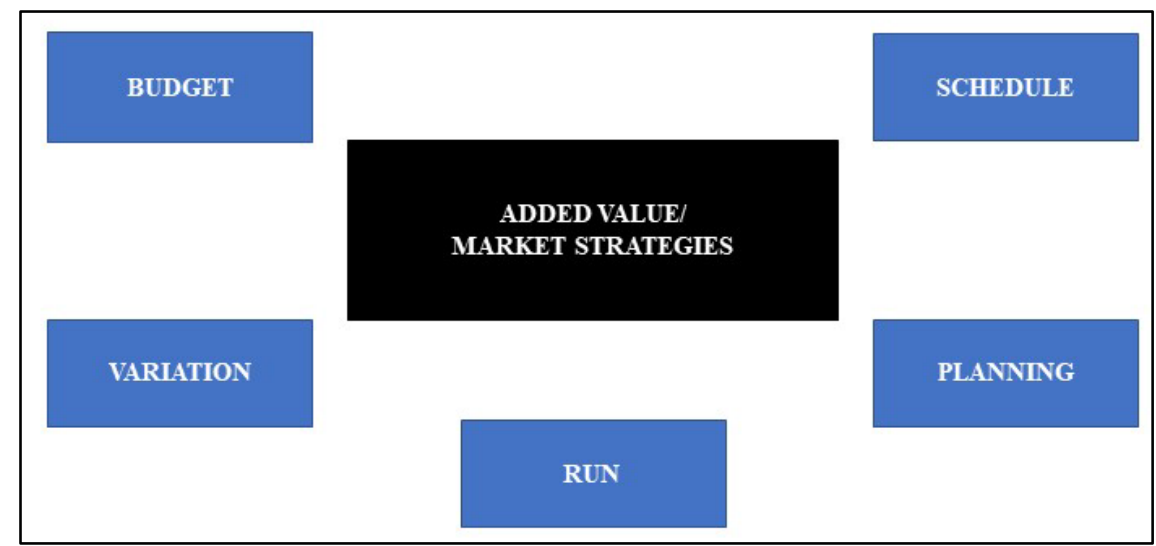

Figure 2: Value x Marketing

Source: elaborated by the authors, based on the research.

According to the model presented in Figure 2, it should be noted that for the strategies that arise through market expansion to have the expected result, the company needs to plan and know the art of properly using physical, financial and financial resources available in it with a view to minimizing problems and maximizing opportunities (Oliveira, 2007).

In this context, market expansion needs to be planned at the "right" time the nonexpansion, can cause market loss and, the only solution ends up being also the sale or association with larger companies, if not the operation becomes unsustainable. These facts indicate the need for the company to maintain constant monitoring of its growth vector and to execute a correct planning of each phase of the expansion process, in this way the opportunities for errors will be minimized (Oliveira, 2007).

\section{WOODRUFF'S (1997) PROPOSAL FOR VALUE DEFINITION}

Woodruff (1997, p.140) puts it: "By customer value we understand the customer's perspective of an organization, whether final consumer, or intermediate, or industrial 
INDEPENDENT JOURNAL OF MANAGEMENT \& PRODUCTION (IJM\&P)

http://www.ijmp.jor.br

v. 12, n. 2, March-April 2021

ISSN: 2236-269X

DOI: 10.14807/ijmp.v12i2.1324

consumer, considering what the customer wants and believes he can buy and use the product of organization." By analyzing a series of definitions proposed by several authors for customer value, Woodruff (1997, p.141) identified areas of consensus and others in which the concepts of value to the client diverge.

Woodruff (1997) pointed out differences in the bases of construction of definitions. First, he stressed that a diversity of terms, such as quality, benefits, value and utility, is employed, without a clear definition of them. The comparison, in this way, becomes more difficult, leading to the following type of questioning: does the value to the client, which has quality as a basis, have the same sense of value for the client, which takes the benefits into account? It is not possible to answer this question without first examining the meaning and secondary concepts, such as quality and benefits, that support the definitions presented.

It also proposes that value to the customer is the next source of competitive advantage for organizations. For Woodruff, a customer-oriented organization needs to learn extensively about the markets and target customers, understanding what their customers understand by value, in what ways the organization should focus its efforts, how well the organization delivers value from the customer's perspective and what customers will value in the future (Woodruff, 1997).

Seeking to understand what value is to the customer (VPC), Woodruff found that the various concepts that have emerged in the last decade differ in meaning, because they use terms such as utility, benefits and quality, which by themselves are not well defined, making difficult to compare concepts. However, these concepts have some similarities: the VPC is inherent or linked to the use of a product; it is something perceived by the client and not objectively defined by the offeror; and involves an exchange between what the customer receives and what gives to purchase or use the product. Woodruff (1997 p. 142) then proposes its definition of VPC:

Customer value is a perceived customer preference for a product and an evaluation of those product attributes, performance of attributes and consequences that arise with the use that facilitate (or hinder) the achievement of the objectives and purposes of the customer in the situations of use.

Finally, the author found differences in the proposed classifications on the types of value for the client. Among the classifications, he showed that of Sheth, Newman and Gross (1991), which distinguishes five value categories that can be provided by a product. Sheth, Mittal and Newman (2001, p. 333) present this value categorization, as described below. 
1. Functional: a product or service satisfies its physical or functional purpose (e.g., cleaning soaps and remedies to relieve physical ailments).

2. Social: a product or service meets social need through its association with certain demographic, socioeconomic, or ethno cultural segments of a society (e.g., wearing Polo shirts to identify with people successful and high-income).

3. Emotional: the product or service satisfies this need by creating appropriate emotions and feelings, such as the joy, love, or respect a person feels when he receives a gift.

4. Epistemic: the product or service satisfies the human need to know or learn something new; for example, buy and read a newspaper, watch a news cast on TV, buy an encyclopedia or books of History, science and commerce.

5. Situational: Certain products or services meet needs that are situational or contingent in a particular place or time: for example, an emergency repair in the car during a trip out of the city.

Woodruff's (1997) conceptualization incorporates the notion of desired and received values and asserts that the value originates from the perceptions learned from the client, as well as from their preferences and evaluations. The definition also highlights the value in situations of use of the product, linking product attributes and their performance to the consequences of use and the objectives intended by the customer with the use of the product (or personal values). The idea of relating attributes, consequences and intended objectives (or personal values) is anchored in the conceptual structure of the half-end chain model (Gutman, 1982) - adapted in Figure 3 by Woodruff and Gardial (1996). 
DOI: 10.14807/ijmp.v12i2.1324

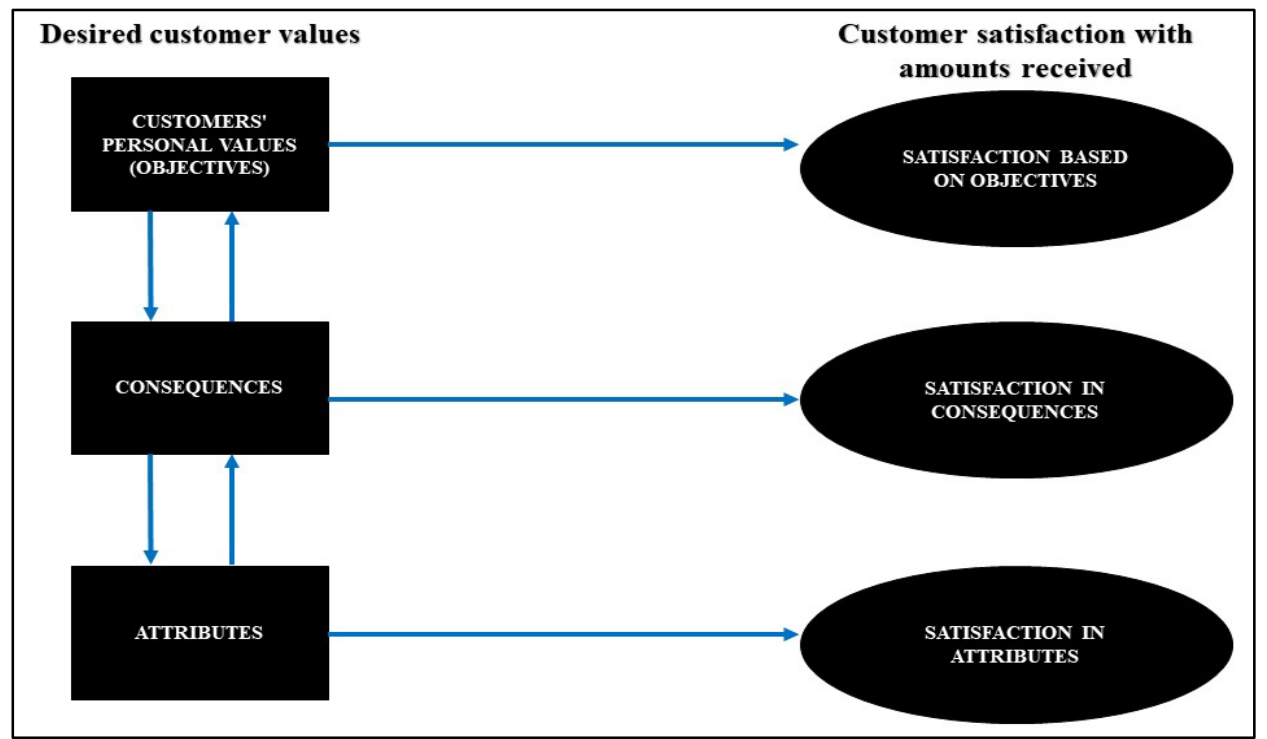

Figure 3: Customer Value Hierarchy Model

Source: adapted from Woodruff (1997); Woodruff and Gardial (1996).

Although Woodruff's definition is broader and does not focus only on "give-versusreceive" assessments, it does not seem to be effective for the operationalization of the construction of scales to measure value for the client. The multiplicity of contexts (pre and post purchase), tasks ("preference for" and "evaluation of") and criteria (product attributes, use consequences and customer objectives), transforms the construction of a scale or indicator that measures the VPC construct into challenge (Parasuraman, 1997). Thus, to really transform value for the customer into a competitive advantage, it is necessary to understand how customers form their perceptions of value and develop ways to measure them.

In line with gaining competitive advantage with value creation, Slater (1997) proposes the development of a firm theory based on value for the client, recognizing that creating value for the client is the reason for the existence of the company and its success. Therefore, the theory of the VPC-based firm would say, according to Slater (1997, p.164), that "the superior performance of companies is due to an organizational culture based on value for the client, complemented by their ability to learn about their customers and about the changes in their needs, for their management of the innovation process and for their organization focused on the processes of delivery of value to the customer."

\subsection{Market Expansion Strategy for the Client}

The market expansion strategy for the customer, provides elements for the organization to align its main indicators of success with meeting customer expectations and market needs, seeking to measure and monitor the value delivered to the customer through its products and / or services. In other words, the VPC can be treated as market orientation. According to Narver 
DOI: 10.14807/ijmp.v12i2.1324

and Slater (1990), the expansion strategy oriented to the market and the customer, seeks to implement, and, create behavior necessary for the generation of value superior to customers and continuous superior performance to the business.

Sheth (2001) coin the term market expansion strategy to define the potential that a product has to satisfy the needs and desires of customers, considering that these needs and desires vary from one person to another.

According to Mckenna (2000, p. 48) "... to survive in dynamic markets, companies need to establish strategies that survive turbulent changes in the market. They have to build strong foundations that are not knocked down by storms," that is, companies need to use all the tools available in the arsenal of marketing communications, using all their creativity and imagination, to add differentiated values and benefits to its customers.

The knowledge that an organization holds about the values in market strategies for customers has implications for marketing management. These include: (a) market strategy and segmentation; (b) strategy for positioning products and brands; (c) strategy for planning and developing products and brands; (d) communication strategy. Each of these points is examined below:

\subsubsection{Market Strategy and Segmentation}

McCarthy (1982, p.173), advocated the adoption of market strategy and segmentation for greater success in achieving the company's objectives, including it in the strategic considerations of the marketing mix. Where the value to the client presents itself as another possibility of market segmentation, because it is possible to identify individuals with similar value orientations in relation to their behaviors (Ikeda \& Oliveira, 2015).

Vinson, Scott and Lamont (1997, p. 48) support this view, admitting that knowledge of value guidelines provides an efficient and measurable set of variables that expand marketers' knowledge beyond demographic differences and psychographic.

According to Richers (1991, p.22), the company should focus its segmentation options from four different angles: that of the sector, which is a problem of competition; the segments, which is a problem of opportunity; that of products, which is an adaptation problem; distribution and communication, which is a problem of choice. Of these four variables, only the latter two lend themselves to manipulation and should therefore be explored as the first to take into account. 
DOI: $10.14807 /$ ijmp.v12i2.1324

The change in values also has important implications for market strategy and segmentation. In this respect, Vinson, Scott and Lamont (1977, p. 48-49) warn that organizations should be more concerned with evaluating changes in the size and composition of value segments and the implications of these changes for marketing. They argue that marketing management could use this information to "identify new product opportunities and modify existing products to be consistent with consumer value profiles."

It was, therefore, based on previous studies on value and behavior of the client (Young \& Feigin, 1975; Howard, 1977; Vinson \& New Life, Scott \& Lamont, 1977) that Gutman (1982) proposed the model of half-end chains, designed to provide a theoretical structure capable of interconnecting the values of consumers to their behaviors.

\subsubsection{Product and Brand Positioning Strategy}

The theoretical conception of product and brand positioning begins in 1969, when Jack Trout wrote the article "Positioning is a game people play in today's me-too market place", in Industrial Marketing. In the article, the author recalls that a position is a relative state and such a concept implies a comparison between competing offers, from their brands with the aim of constructing a meaning (Trout, 1969).

Keller and Machado (2006) created a model for creating positioning for a brand. The authors argue that deciding positioning requires: 1) determining the reference structure (identifying the target audience and competitor) and 2) defining the ideal brand associations (parity points and points of difference). In this case, parity points would aim to place the mark in relation to a given category, while the points of difference would fulfill the function of creating the differentiations in relation to that target competitor.

The suggestion of Vriens and Hofstede (2000) is that once the attributes, consequences and personal values are identified, the respondents evaluate the brand at each of the levels considered, enabling the positioning of the same at all levels. Reynolds and Gutman (1988, p. 26) explain that for many product categories or subclasses of categories, it is more likely that respondents' judgment on preferences for a product or brand is made at the levels of consequence and personal value, rather than at the attribute level.

Vriens and Hofstede (2000, p. 4) argue that often, "in marketing research, products and brands are characterized as a set of attributes and that this is not sufficient for positioning". They argue that attribute quantification does not always provide a panacea for brand positioning and the development of communication strategies. 
DOI: 10.14807/ijmp.v12i2.1324

\subsubsection{Product and Brand Planning and Development Strategy}

In today's context, in an open and competitive society, the first challenge or first function of an entrepreneur is to anticipate the needs of one or more markets in the immediate and long-term future. Therefore, the strategy of planning and development of products and brands are how they constitute the basis of a company's operations (Gobe et al., 2004).

According to Vriens and Hofstede (2000, p. 7), the key element in the successful development of a product is the clear identification of the central benefit provided by it, which, in the authors' opinion, is associated with a "short list of strategic benefits that the new product provides and how the product will provide these benefits."

Companies can add new products through acquisitions or product and brand development. However, the acquisition process can take three forms: such as buying from other companies, acquiring patents from other companies, or purchasing a license or franchise from another company (Kotler \& Keller, 2006). Gutman (1982, p. 71) considers that the fact that product attributes are used by consumers to infer the presence of desired consequences allows clarifying specifications for product development.

In this sense, a new product can be considered as the development and introduction of a product, not previously manufactured by the company, on the market or the presentation of a new product already existing in a new market not previously operated by the company (Back \& Forcellini, 2001). "For the standard product development process to be used by multiple people, it is documented in the form of a model" (Rozenfeld et al., 2006, p.41).

Likewise, Gobe et al (2004) points out that at this stage the product formula, its measurements, colors, sizes, models, aromas, flavors, dimensions, etc., as well as the packaging, name and brand, desired price level are defined; that is, the main elements of the marketing compound.

\subsubsection{Communication Strategy}

In what sense can we qualify "communicative" and "strategic"? Perez (2012, p.124) also poses an important and fundamental question when he speaks "¿de qué estratégia y de que comunicación estamos hablando?". Can we say that strategic communication and communication strategies are the same thing or are there characteristics that differentiate them and above all, whether they are relevant for communication strategy studies in organizations? 
DOI: 10.14807/ijmp.v12i2.1324

Vinson, Scott and Lamont (1977, p. 48-49) believe that promotional messages can be developed not only to refer to desired attributes in a product, but also to consider the values associated with these attributes. According to Reynolds and Whitlark (1995, p. 10), the most obvious communication strategy is simply to reinforce the existing links between the distinctive attributes of a product and the consequences and values relevant to the consumer, to which they are associated.

The idea of Vriens and Hofstede (2000, p 7-8) "is that consumers are asked about the values that advertising evokes, which provides perceptual guidance, as it indicates the positions that are clear, as well as those that need to be reinforced or announced".

In this interim, most theories and methodologies place the communication strategy as a broad and systematic process. The authors Oliveira and Paula (2007, p.41) consider that "... gain strength the idea of strategic thinking and shared methodologies of communication strategies, capable of delineating directions with long-term focus, aimed at generating value [...]."

For Oliveira and Paula, it is necessary to understand the communication strategy reference from at least two relevant aspects: the first, from the perspective of organizations, refers to the alignment of communication with strategic objectives and the achievement of organizational results. The second concerns the mediating character of the internal and external environment, with respect to the insertion of social actors in organizational decisions (Oliveira \& Paula, 2007, p.42).

This position is in line with the thinking of Reynolds and Whitlark (1995, p. 10), who warn that communication strategies should not be based only on the results obtained with the structure of medium-end chains; in addition, it is important to consider external factors that also influence the scope and nature of strategic objectives.

\section{FINAL CONSIDERATIONS}

In view of the above, the concepts discussed in this study, it is evident that the client's perspective linked to a market expansion strategy is directly linked to the customer experience with all the tangible and intangible elements that make up an offer . Therefore, companies need to have greater visibility not only of their products and services offered, but also of the entire system in which they are, including all the experiences involved during this contact.

It can be highlighted that the perspective of VPC linked to a strategy of market expansion is closely linked to what the customer seeks in the current market (product and/or 
DOI: 10.14807/ijmp.v12i2.1324

service), but at the same time the client seeks to be valued (instigated to participate in the generation of value of products and/or services) in organizations, strengthening affective bonds in certain organizations.

Furthermore, this study aimed to show in different concepts what generates value for the client in marketing administration. For offering or adding value is a concept directly related to customer satisfaction, one of the main objectives of marketing, vargo points out and Lusch (2007) defines the concept of value for the client, where it is used for the measurement of benefit received, and, in this context, the value of use is related to the work in the organization, as well as the results achieved by it.

In this way, the activities to increase the value perceived by the customer should be in line with what he expects, and yearns for the product, offer, service or company. Where, the increase in the value perceived by the client should follow this basic formula, increase the benefits and reduce costs, but what should be the priorities, where to start and how to do this so that the client is impacted and valued by the proposed actions companies in generating value for the client (Junior, 2010).

Therefore, the realization of this research, through a bibliographic analysis, also resulted in some aspects that need to be mentioned: it presents an important contribution in marketing administration, when applying theories about perspective value for the client linked to a market expansion strategy.

It also showed a marketing concept; concept of value; value from a customer perspective versus market expansion strategy; Woodruff's proposal (1997) for value definition, and market expansion strategy and its implications. As a research possibility, the perspective of value for the client with a multidimensional possibility linked to education in distance higher education stands out.

\section{REFERENCES}

Back, N., \& Forcellini F. A. (2001). Projeto de produtos. Curso de Pós-Graduação em Engenharia Mecânica. UFSC. Apostila.

Barney, J. B., Hesterly, W. S., \& Rosemberg, M. (2007). Administração estratégica e vantagem competitiva. Pearson Educación.

Berry, L. L., Shankar, V., Parish, J. T., Cadwallader, S., \& Dotzel, T. (2006). Creating new markets through service innovation. MIT Sloan management review, 47(2), 56.

Child, J. (1997). Strategic choice in the analysis of action, structure, organizations and environment: Retrospect and prospect. Organization studies, 18(1), 43-76. 
DOI: 10.14807/ijmp.v12i2.1324

Cobra, M., \& Ribeiro, Á. (2000). Marketing: magia e sedução. Cobra.

Costa, E. A. (2006). Gestão estratégica. 6. ed., São Paulo. Saraiva.

Drucker, P. F. (1994). A teoria dos negócios. Boston: Harvard Business Review.

Fonseca, D. (2015). A cocriação de valor no desenvolvimento de uma nova marca na indústria farmacêutica em Portugal. (Doctoral dissertation).

Forcellini, F., \& Rozenfeld, H. (2006). Gestão de desenvolvimento de produtos: uma referência para a melhoria do processo. São Paulo: Saraiva.

Frio, R. S., Brasil, V. S., \& Dietrich, J. F. (2013) O Processo de Cocriação de Valor entre Empresas e Consumidores: uma análise comparativa de dois casos da indústria de bens de consumo. Revista de Administração IMED.

Gobe, A. C., et al. (2004). Gerência de produtos. São Paulo: Saraiva.

Gummesson, E. (2007). Exit services marketing-enter service marketing. Journal of customer behaviour, 6(2), 113-141.

Gutman, J. (1982). Um modelo de cadeia de meios-fim baseado em processos de categorização do consumidor. The Journal of Marketing, 60-72.

Howard, J. A. (1977). Consumer behavior: Application of theory. McGraw-Hill Companies.

Ikeda, A. A. (2005). MODESTO VELUDO-DE-OLIVEIRA, T. O conceito de valor para o cliente: definições e implicações gerenciais em marketing. REAd-Revista Eletrônica de Administração, 11(2).

Jensen, P. A. (2005). Value concepts and value-based collaboration in building projects. Proceedings of CIB W096 Architectural Management, 3-10.

Junior, J. H. R. (2010). O valor percebido e 0 cliente. http://www.portaldomarketing.com.br/Artigos/Valor_Percebido_e_o_Cliente.htm. Acesso em 04 de set. de 2018.

Keller, K. L., Machado, M., \&Marques, A. S. (2006). Gestão estratégica de marcas. Pearson Educación, 2006.

Kotler, P. (2012). Kotler on marketing. Simon and Schuster.

Kotler, P., \& Keller, K. L. (2006). Administração de marketing. Tradução de: Mônica Rosenberg, Brasil Ramos Fernandes e Cláudia Freire.

Las Casas, A. L. (2008). Marketing educacional: da educação infantil ao ensino superior no contexto brasileiro. São Paulo: Saint Paul.

Lindgreen, A., \& Wynstra, F. (2005). Value in business markets: What do we know? Where are we going?. Industrial Marketing Management, 34(7), 732-748.

Mccarthy, E. J. (1982). Marketing. Rio de Janeiro. Campus.

Mckenna, R. (2000). Marketing de relacionamento. São Paulo: Campus.

Narver, J. C., \& Slater, S. F. (1990). The effect of a market orientation on business profitability. The Journal of marketing, 20-35.

North, G. (1992). The Coase theorem: a study in economic epistemology. Inst for Christian Economics. 
Oliveira, G., Damacena, C., \& Brambilla, F. R. (2014). Cocriação como proposta para geração de valor: caso da empresa dental américa. Desenvolve Revista de Gestão do Unilasalle, 3(2), 129-150.

Oliveira, I. L., \& Paula, M. A. (2007) O que é comunicação nas organizações?. $2^{a}$ ed. São Paulo: Paulus.

Parasuraman, A. (1997). Reflections on gaining competitive advantage through customer value. Journal of the Academy of marketing Science, 25(2), 154.

Prahalad, C. K. et al. (2004). Estratégia: a busca da vantagem competitiva. 18. Ed. Rio de Janeiro: Campus.

Perez, R. A. (2018). La estrategia como campo de estudio. ¿Tenemos ya un nuevo paradigma?. Revista Mediterránea de Comunicación, 5(2), 9-31. Disponível em: $<$ http://mediterranea-comunicacion.org/>. Acesso em 04 de set.

Reynolds, T. J., \& Whitlark, D. B. (1995). Escada de dados para a estratégia de comunicação e prática publicitária. Jornal de pesquisa publicitária.

Reynolds, T. J., \& Gutman, J. (1988). Laddering theory, method, analysis, and interpretation. Journal of Advertising Research, New York, 28, 11-31, Feb./Mar.

Richers, R. (1991). Segmentação de mercado: uma visão de conjunto. In: Richers, R., Lima, C. P. Segmentação: opções estratégicas para o mercado brasileiro. São Paulo: Editora Nobel.

Richins, M. L. (1994). Valuing things: The public and private meanings of possessions. Journal of consumer research, 21(3), 504-521.

Santos, T., Lima, M. V. V., Brunetta, D. F., Fabris, C., \& Seleme, A. (2009). O desenvolvimento do marketing: uma perspectiva histórica. REGE Revista de Gestão, 16(1), 89-102.

Saraceni, S. (2015). Cocriação de valor no relacionamento empresa-cliente: um estudo exploratório (Doctoral dissertation, Universidade de São Paulo).

Schmitt, B. H. (2002). Marketing experimental-Exame. NBL Editora.

Sheth, J. N., Mittal, B., \& Newman, B. (2001). Comportamento do cliente: indo além do comportamento do consumidor. São Paulo: Atlas.

Sheth, J. N., Newman, B. I., \& Gross, B. L. (1991). Consumption values and market choices: theory and application. Cincinnati: South-Western.

Shostack, G. L. (1977). Breaking free from product marketing. The Journal of Marketing, 73-80.

Slack, R. A. (1998). The application of lean principles to the military aerospace product development process (Doctoral dissertation, Massachusetts Institute of Technology).

Slater, S. F. (1997). Desenvolver uma teoria da empresa baseada no valor do cliente. Jornal da Academia de Marketing Science, 25(2), 162.

Trout, J. (1969). Positioning is a game people play in today's me-too market place. Industrial Marketing, v.54, n 6, June.

Vargo, S. L., \& Lusch, R. F. (2012). The nature and understanding of value: A servicedominant logic perspective. In Special Issue-Toward a Better Understanding of the Role of Value in Markets and Marketing (pp. 1-12). Emerald Group Publishing Limited. 
Vargo, S. L., \& Lusch, R. F. (2008). Service-dominant logic: continuing the evolution. Journal of the Academy of marketing Science, 36(1), 1-10.

Vargo, S. L., \& Lusch, R. F. (2004). Evolving to a new dominant logic for marketing. Journal of marketing, 68(1), 1-17.

Vinson, D. E., Scott, J. E., \& Lamont, L. M. (1977). O papel dos valores pessoais no marketing e no comportamento do consumidor. O Jornal de Marketing, 44-50.

Vriens, M., \& Hofstede, F. T. (2000). Linking Attribute, Benefits, and Consumer Values. marketing research, 12(3).

Woodruff, R. B. (1997). Valor para o cliente: a próxima fonte de vantagem competitiva. Jornal da academia de marketing science, 25 (2), 139.

Woodruff, R. B., \& Gardial, S. (1996). Know your customer: New approaches to understanding customer value and satisfaction. Wiley.

Young, S., \& Feigin, B. (1975). Utilizar a cadeia de benefícios para melhorar a formulação da estratégia. The Journal of Marketing, 72-74. 